\title{
Use of benzodiazpines in the treatment of major depressive disorder in an outpatient mental health center
}

\author{
Carolina Garnier ${ }^{*}$, Belen Diaz, Patricia Alvaro, Rosa Sanchis, Juan Castaño, David Corcoles, Francisco Portillo, \\ Luis Miguel Martin, Antoni Bulbena
}

From $1^{\text {st }}$ International Congress on Neurobiology and Clinical Psychopharmacology and European Psychiatric Association Conference on Treatment Guidance

Thessaloniki, Greece. 19-22 November 2009

\section{Background}

The reviewers report that a combination of benzodiazepines (BZD) with antidepressants work in favour for the treatment of depression, because it decreases drop outs of treatment and it increases short-term response up to four weeks [1]. Early achievement of symptomatic remission is critical to the long-term success of treatment [2].

\section{Materials and methods}

Using a sample of 100 patients with MDD who have been visited in Barcelona's Sant Martí Sud outpatient mental health center during the year 2008, sociodemographical (gender, age) and clinical data (toxic consume, psychiatric background, use of BZD) are analysed with SPSS 15.0 statistical package

\section{Results}

There is use of BZD in a 76\% of the sample, with a predominancy of the female gender ( $72.4 \%$ vs $27.6 \%)$, a global average age of $56.55 \pm 12.4$ years. In relation to personal psychiatric background it can be observed in $47.4 \%$ the absence of these, followed by $39.5 \%$ in which there is presence of previous depressive episodes. There is a predominancy in the absence of toxic abuse (97.4\%) and the absence of previous hospitalisations (81\%)

It can be observed the following distribution by frequencies in the use of BZD: diazepam (25\%), dipotassic clorazepate $(23,7 \%)$, clonazepam $(14.5 \%)$ and alprazolam (10.5\%). The average dose was $10.2 \mathrm{mg} / \mathrm{d}$ for diazepam, $22.9 \mathrm{mg} / \mathrm{d}$ for dipotasic clorazepate, $2.7 \mathrm{mg} / \mathrm{d}$ for clonazepam and $1 \mathrm{mg} / \mathrm{d}$ for alprazolam.

Department of Psychiatry, Hospital del Mar, IAPS, Barcelona, Spain

\section{Conclusions}

The use of BZD in the DMM is large in our sample but the potential benefits of adding a BZD to an antidepressant must be balanced judiciously against possible harms including development of dependence and accident proneness, on the one hand, and against continued suffering following no response and drop out, on the other.

Published: 22 April 2010

\section{References}

1. Furukawa TA, Streiner DL, Young LT, Kinoshita Y: Antidepressant plus benzodiazepine for major depression. Cochrane Database Syst Rev 2001, 2: CD001026.

2. Craig Nelson J, Pikalov A, Berman R: Augmentation treatment in major depressive disorder: focus on aripiprazole. Neuropsychiatri Dis Treat San Francisco 2008, 4(5):937-948.

doi:10.1186/1744-859X-9-S1-S170

Cite this article as: Garnier et al:: Use of benzodiazpines in the

treatment of major depressive disorder in an outpatient mental health center. Annals of General Psychiatry 2010 9(Suppl 1):S170.

Submit your next manuscript to BioMed Central and take full advantage of:

- Convenient online submission

- Thorough peer review

- No space constraints or color figure charges

- Immediate publication on acceptance

- Inclusion in PubIMed, CAS, Scopus and Google Scholar

- Research which is freely available for redistribution 